\title{
Variant clinical courses in children with immune thrombocytopenic purpura: Sixteen year experience of a single medical center
}

\author{
Çocukluk çă̆ında immun trombositopenik purpura ve farklı klinik \\ seyir: Tek merkezin 16 ylllı deneyimi
}

\author{
Işın Yaprak, Berna Atabay, İkbal Durak, Meral Türker, Haldun Öniz, Esra Arun Özer \\ Izmir Tepecik Training and Research Hospital, İmir, Turkey
}

\begin{abstract}
Objective: Immune thrombocytopenic purpura (ITP) is the most common cause of acquired thrombocytopenia in children. The objective of this study was to evaluate the presenting features, variation in the clinical courses, initial response rate to therapy, and long-term outcome in patients with ITP. Materials and Methods: Three hundred and fifty out of 491 newly diagnosed patients with ITP between the initial diagnosis ages of 6 months to 16 years were included in this retrospective, descriptive study. Patients with acute vs chronic ITP, acute vs recurrent ITP and chronic vs recurrent ITP were compared in terms of age at diagnosis, gender, initial platelet count, response rate to initial therapy, long-term outcome, and total duration of follow-up.

Results: The clinical courses of the patients were determined as acute, chronic and recurrent in $63.8 \%$, $29.1 \%$, and $7.1 \%$, respectively. Platelet count $>20 \times 109 / \mathrm{L}$ and initial diagnosis age $>10$ years were found to increase the probability of chronic outcome by at least two-fold.

Conclusion: It is concluded that ITP in childhood is a common disease with low morbidity and mortality. In addition to the acute and chronic form, a rare recurrent form, which accounts for about $4-7 \%$ of all ITP patients, should be considered. (Turk J Hematol 2010; 27: 147-55)

Key words: Immune thrombocytopenic purpura, children, clinical course, chronic, recurrent, outcome
\end{abstract}

Received: June 2, 2009

Accepted: March 22, 2010

Özet

Amaç: İmmun trombositopenik purpura (ITP) çocukluk çağında en sık görülen edinsel trombositopeni nedenlerindendir. Bu çalışmada, ITP'li çocuklarda başvuru bulguları, klinik seyirlerindeki farklılıklar, tedaviye ilk yanıt ve uzun dönem prognozlarının değerlendirilmesi amaçlandı.

Yöntem ve Gereçler: Bu retrospektif, tanımlayıcı araştırmaya tanı yaşı 6 ay-16 yıl olan ITP'li 491 hastadan 350'si dahil edildi. Akut, kronik ve rekürren ITP'li olgular tanı yaşı, cinsiyet, başvurudaki trombosit sayısı, ilk tedavi yanıtı, prognoz ve izlem süreleri yönünden ikili gruplar halinde karşılaştırıldı.

Bulgular: Hastaların \%63.8'i akut, \%29.1'i kronik ve \%7.1'i rekürren ITP olarak tanımlandı. Trombosit 
sayısı $>20 \times 10^{9} / \mathrm{L}$ ve başvuru yaşının $>10$ yaş olmanın kronik ITP olasılığını 2 kat arttırdığı görüldü. Sonuç: Sonuç olarak ITP, çocukluk yaş grubunda mortalite ve morbiditesi düşük bir hastalıktır. Akut ve kronik seyirli ITP dışında, tüm ITP olgularının \%4-7'sini oluşturan rekürren formların da olabileceği akılda tutulmalıdır. (Turk J Hematol 2010; 27: 147-55)

Anahtar kelimeler: İmmun trombositopenik purpura, çocuk, klinik seyir, kronik, rekürren, prognoz

\section{Introduction}

Immune thrombocytopenic purpura (ITP) is a common acquired bleeding disorder characterized by increased destruction of antibody-sensitized platelets with normal to increased megakaryocytes in the bone marrow, presence of thrombocytopenia with otherwise normal red cells and leukocytes, absence of splenomegaly, and absence of other causes of thrombocytopenia [1,2]. Variability in the natural history and response to therapy suggest that ITP comprises a heterogeneous pathophysiology [3]. ITP affects infants, children, and adults; in the majority of the children, it is an acute, self-limiting disorder with complete resolution of the illness occurring within six months. However, $15 \%-30 \%$ of the children with ITP develop the chronic form of the disease defined as persistence of thrombocytopenia beyond six months. Children with chronic ITP (cITP) manifest variable clinical features and management is controversial [1-5]. Response rate to treatment is usually low in cITP; however, in some studies, high rates of spontaneous remission have been reported [6-8].

In addition to the acute and chronic forms of the disease, a recurrent course is also encountered in children. Recurrent ITP (rITP) is characterized by intermittent episodes of thrombocytopenia followed by periods of recovery, unrelated to therapeutic intervention $[9,10]$. Although first described in 1961 [11], literature on this clinical course of the disease is limited.

At present, the natural course of ITP is not fully understood. There are no established criteria regarding the clinical characteristics of the variant clinical courses, in order to predict the time and risk factors for a chronic outcome, response to treatment and/or ultimate outcome. Furthermore, there is controversy regarding the classification of patients with recurrences.

The objective of our study was to evaluate the presenting features, diversity in clinical courses (including patients with recurrences), response to initial therapy, and long-term outcome in patients with ITP treated in our Pediatric Hematology Division and to share our single-institution, long-term, hospital-based experience together with related information in the literature.

\section{Materials and Methods}

\section{Data Collection and Diagnosis}

This retrospective, descriptive, cohort study was performed on patients with ITP diagnosed and followed from January 1990 to December 2006 in the Pediatric Hematology Division, Tepecik Training and Research Hospital, İzmir, Turkey. Data regarding 491 children with ITP were evaluated. There is ethical committee approval for the study. Patients less than 6 months and over 16 years at initial diagnosis, noncompliant patients and patients with proven secondary ITP were excluded. A total of 350 patients (186 females, 164 males) between the ages of 6 months to 16 years were included in the study.

Diagnosis of ITP was made by detailed physical examination and history, presence of thrombocytopenia $\left(<150 \times 10^{9} / \mathrm{L}\right)$ with otherwise normal red cells and leukocytes, evaluation of Giemsa-stained peripheral blood smear and bone marrow aspiration, and serological tests for infectious causes and autoimmune diseases [1].

Data collected from patients' records included presenting hemorrhagic symptoms, age at diagnosis, gender, platelet count (PC) at diagnosis, the onset of each recurrence, number of recurrences, time elapsed between recurrences and from the initial diagnosis, treatment modality, response to treatment, follow-up duration, type of clinical course, preceding viral or bacterial infection, and medication or vaccination history.

\section{Definitions}

Patients having low PC $(<150 \times 109 / \mathrm{L})$ for less than 6 months were defined as acute ITP (aITP) and patients with thrombocytopenia persisting for more than 6 months after initial diagnosis were defined as cITP. Complete remission was defined as PC $>150 \times 109 / \mathrm{L}$ whereas partial remission was PC 
between 50-150x109/L. Patients achieving complete remission after initial diagnosis, but showing recurrences after at least 3 months of remission (with normal PCs) sustained without treatment and then relapsed were defined as rITP [10] (they achieved complete response to therapy after each recurrence and then relapsed). cITP patients were also evaluated in late-remission and non-remission subgroups. Chronic patients achieving normal PC after at least 6 months (usually 1-10 years) and maintaining the normal PC values thereafter were defined as late-remission cITP. Patients who did not achieve normal PC values within the entire follow-up period were defined as non-remission cITP.

\section{Treatment}

Patients with PC $<20 \times 109 / \mathrm{L}$ and/or bleeding symptoms at initial diagnosis were treated. Treatment consisted of high-dose methyl prednisolone (HDMP) or intravenous immunoglobulin (IVIG) and combination therapy of HDMP and IVIG, if the third-day PCs were still $<20 \times 109 / \mathrm{L}$. In patients $\leq 2$ years, the first choice of therapy was IVIG, whereas HDMP was the first choice in patients $>2$ years. IVIG was given at a dose of $1 \mathrm{~g} / \mathrm{kg} /$ day for 2 days; HDMP was given at a dose of $30 \mathrm{mg} / \mathrm{kg} /$ day for 3 days and $20 \mathrm{mg} / \mathrm{kg} /$ day for 4 days, consecutively and intravenously. For children $>6$ years, HDMP was given either orally or intravenously at the same dosage [5]. Regarding criteria for response to treatment, complete response (CR) was defined as $\mathrm{PC} \geq 150 \times 10^{9 /} \mathrm{L}$ and partial response (PR) as PC 50-149x109/L, including clinical recovery. $\mathrm{PC}<50 \times 10^{9} / \mathrm{L}$ was defined as nonresponsive (NR).

\section{Evaluation and Statistical Analysis}

For statistical analysis, SPSS for Windows version 13.0 was used. Independent samples t-test, Pearson $\chi^{2}$ test, Mann-Whitney $U$ test and linear regression analysis were used. $\mathrm{p}<0.05$ was accepted as statistically significant.

\section{Results}

Among 350 patients with ITP, 186 were females; $96.7 \%$ had presented with minor bleeding symptoms, either skin and/or mucosal hemorrhage. Three patients presented with epistaxis requiring nasal packing, 5 with gross hematuria and 5 with gastrointestinal bleeding in addition to minor bleed- ing symptoms. $71 \%$ of the patients gave a history of viral illness 3-6 weeks prior to admission.

Median age at diagnosis was 60 months (6 months-16 years) and median initial PC was $9 \times 10^{9} / \mathrm{L}$. Overall, patients were followed for a median 42 months (range: 7 months-16 years). Clinical forms were determined as aITP in $63.8 \%$, cITP in $29.1 \%$ and rITP in $7.1 \%$.

Demographic, clinical and laboratory data of the aITP, cITP and rITP patients are shown in Table 1. Patients with aITP presented at a younger age (median 54 months) than both recurrent (median 75 months) and chronic (median 78 months) patients ( $\mathrm{p}<0.05, \mathrm{p}<0.05) .22 .5 \%$ of chronic patients, $20 \%$ of recurrent patients and $11.7 \%$ of the aITP patients were $>10$ years of age. Initial PCs in aITP and rITP patients were significantly lower than in cITP $(p<0.05, p<0.05)$. PC $>20 \times 109 / \mathrm{L}$ and initial diagnosis age $>10$ years were found to increase the probability of chronic outcome (odds ratio $[\mathrm{OR}]=2$ ) by at least two-fold. Concerning the initial response rate to treatment, $C R$ plus $P R$ rates were highest in acute cases $(87.4 \%)$, whereas $37.2 \%(n=38)$ of the chronic patients were found to be nonresponders. Three patients (12\%) with rITP did not respond initially to HDMP but achieved CR by combination therapy (IVIG and HDMP) within 45-90 days.

Comparison of the general characteristics of the aITP and cITP are shown in Table 2. Statistical differences were found in age at diagnosis, $\mathrm{PC}$ at diagnosis and response rate to initial treatment between acute and overall cITP ( $\mathrm{p}<0.05)$.

Age at diagnosis was not different in cITP vs rITP patients, whereas a significant difference was shown in aITP vs rITP patients ( $p>0.05)$. PC at diagnosis and response rate to initial treatment were not found statistically different between acute and recurrent patients ( $p>0.05)$. However, PC at diagnosis showed significant difference in cITP vs rITP $(p<0.05)$. Initial response rate to treatment showed marginal significance between cITP and rITP $(p=0.05)$.

Regarding the 102 cITP patients, $77.5 \%$ were found to be in the non-remission group, whereas $22.5 \%(n=23)$ achieved remission in a median 18 months (8-66 months). Median age at diagnosis of the patients in non-remission and late-remission groups was 96 months and 42 months, respectively $(p<0.05) .27 .8 \%$ of the patients with non-remission cITP were $>10$ years of age, whereas $4.3 \%$ of the late remission group was $>10$ years at initial diagno- 
sis $(p=0.00)$. PC at initial diagnosis was similar but PC distribution within the follow-up period approached statistical significance between the two groups $(\mathrm{p}=0.000)$. Current status revealed no complete remission and $27.8 \%$ partial remission in patients with non-remission cITP, whereas all of the patients in late-remission cITP achieved complete remission during the follow-up period (Table 3 ).

Detailed data on the patients with rITP are presented in Table 4 and general characteristics and outcome of patients with rITP are given in Table 5 . Median age at initial diagnosis of these patients was 75 months (range: 22-146 months) with female pre- dominance. PC at initial diagnosis was a median $6 \times 10^{9} / \mathrm{L}$. After achieving complete remission in a median 20 days (at initial diagnosis) and sustaining normal PC for a median 20 months, these patients experienced 1-4 recurrences within the follow-up period of 18-141 months. Fifteen patients (60\%) had only one recurrence, whereas 7 (28\%) patients had 2, 2 (8\%) patients had 3, and 1 (4\%) patient had 4 recurrences. The first recurrence was seen between 8-109 months (median 20 months) after initial diagnosis. Time elapsed to $2^{\text {nd }}, 3^{\text {rd }}$ and $4^{\text {th }}$ recurrence after diagnosis was 29, 67 and 58 months, respectively (range: 12-117 months). Duration of each

Table 1. Demographic, clinical and laboratory data of the patients with aITP, cITP and rITP

\begin{tabular}{|c|c|c|c|}
\hline & Acute & Chronic & Recurrent \\
\hline No. of patients & 223 & 102 & 25 \\
\hline Gender, F/M & $119 / 104$ & $53 / 49$ & $14 / 11$ \\
\hline Age at initial diagnosis (months) * & $54(6-164)$ & $78(6-192)$ & $75(22-146)$ \\
\hline \multicolumn{4}{|l|}{ Age distribution at diagnosis, n (\%) } \\
\hline 6-24 months & $48(21.5)$ & $12(11.8)$ & $1(4)$ \\
\hline 25-60 months & $76(34.1)$ & $30(29.4)$ & $9(36)$ \\
\hline 61-120 months & $73(32.7)$ & $37(36.3)$ & $10(40)$ \\
\hline$>120$ months & $26(11.7)$ & $23(22.5)$ & $5(20)$ \\
\hline Platelet count at diagnosis $\left(\times 10^{9} / \mathrm{L}\right) *$ & $8(1-77)$ & $14(1-83)$ & $6(1-30)$ \\
\hline Platelet count at 1 month $\left(\mathrm{x} 10^{9} / \mathrm{L}\right) *$ & $21(7-72)$ & $30(1-43)$ & $131(27-324)$ \\
\hline \multicolumn{4}{|l|}{ Response to initial treatment, n (\%) } \\
\hline Complete response & $130(58.2)$ & $27(26.5)$ & $12(48)$ \\
\hline Partial response & $65(29.2)$ & $37(36.3)$ & $9(36)$ \\
\hline No response & $28(12.6)$ & $38(37.2)$ & $3(12)$ \\
\hline Follow-up duration (months) * & $36(7-132)$ & $54(8-174)$ & $72(18-141)$ \\
\hline
\end{tabular}

* Data are presented as median values (range)

Table 2. Comparison of the general characteristics of the patients with aITP and cITP

\begin{tabular}{lccc}
\hline & Acute & Chronic & p \\
\hline Gender, F / M & $119 / 104$ & $53 / 49$ & 0.81 \\
Age at diagnosis (months)* & $54(6-164)$ & $78(6-192)$ & 0.00 \\
PC at diagnosis (x109/L)* & $8(1-77)$ & $14(1-83)$ & 0.00 \\
$\quad<20 \times 10^{9} / \mathrm{L}, \mathrm{n}(\%)$ & $184(82.5)$ & $65(63.7)$ & 0.00 \\
$\quad>20 \times 10^{9} / \mathrm{L}, \mathrm{n}(\%)$ & $39(17.5)$ & $37(36.3)$ & \\
Response to initial treatment n(\%) & & $27(26.5)$ & 0.00 \\
$\quad$ Complete response & $130(58.2)$ & $37(36.3)$ & $38(37.2)$ \\
$\quad$ Partial response & $65(29.2)$ & $54(8-174)$ & 0.00 \\
Follow-up duration (months) & $28(12.6)$ & $36(7-132)$ &
\end{tabular}

* Data are presented as median values (range) 
Table 3. Comparison of the 102 patients with cITP with different clinical courses

\begin{tabular}{|c|c|c|c|}
\hline & Non-remission & Late-remission & $\mathbf{p}$ \\
\hline No. of patients & 79 & 23 & \\
\hline Gender, F /M & $44 / 35$ & $9 / 14$ & 0.16 \\
\hline Age at diagnosis (months) $*$ & $96(12-193)$ & $42(6-149)$ & 0.00 \\
\hline \multicolumn{4}{|l|}{ Age distribution at diagnosis, n (\%) } \\
\hline 6-24 months & $6(7.6)$ & $6(26.1)$ & \multirow{3}{*}{0.00} \\
\hline 25-120 months & $51(64.6)$ & $16(69.6)$ & \\
\hline$>120$ months & $22(27.8)$ & $1(4.3)$ & \\
\hline $\mathrm{PC}$ at diagnosis $\left(\mathrm{x} 10^{9} / \mathrm{L}\right) *$ & $14(1-83)$ & $13(1-76)$ & 0.81 \\
\hline Months to achieve remission * & & $18(8-66)$ & - \\
\hline Post-remission follow-up (months) * & - & $42(8-118)$ & - \\
\hline Total follow-up (months) * & $54(8-180)$ & $72(18-156)$ & 0.12 \\
\hline \multicolumn{4}{|l|}{ Current status n (\%) } \\
\hline Complete remission & 0 & $23(100)$ & \multirow{3}{*}{-} \\
\hline Partial remission & $22(27.8)$ & 0 & \\
\hline No remission & $57(72.2)$ & 0 & \\
\hline
\end{tabular}

Table 4. Clinical and laboratory characteristics of thrombocytopenic episodes in rITP

\begin{tabular}{|c|c|c|c|c|c|}
\hline 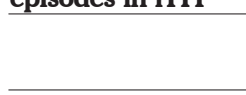 & $\begin{array}{c}\text { Initial } \\
\text { Diagnosis }\end{array}$ & $1^{\text {st }}$ & $2^{\text {nd }}$ & $3^{\text {rd }}$ & $4^{\text {th }}$ \\
\hline No. of patients & 25 & 25 & 10 & 3 & 1 \\
\hline $\mathrm{PC} \times 10^{9} / \mathrm{L}^{*}$ & $6(1-30)$ & $9(4-45)$ & $11(8-22)$ & $4(3-8)$ & 37 \\
\hline $\begin{array}{l}\text { Bleeding } \\
\text { manifestations** }\end{array}$ & 25 & 20 & 7 & 1 & 0 \\
\hline \multicolumn{6}{|c|}{ Treatment/no response } \\
\hline IVIG or HDMP & $24 / 3$ & $22 / 4$ & $8 / 0$ & $2 / 0$ & 0 \\
\hline IVIG+HDMP & $3 / 0$ & $4 / 0$ & 0 & 0 & 0 \\
\hline No treatment & $1 /-$ & $3 /-$ & $2 /-$ & 1/- & $1 /-$ \\
\hline
\end{tabular}

recurrence was 5-11 days. Time interval between the recurrences was a median 12 months (range: 4-50 months). Time elapsed after last remission was a median 24 months (6-99 months). Currently, these patients are all in complete remission.

Out of 102 cITP patients, 30 (29.4\%) underwent splenectomy. Median ages at diagnosis and at splenectomy of these patients were 8.5 years and 10.7 years, respectively. Patients were followed 12-170 months after splenectomy, and within this period, $73.3 \%$ achieved complete remission.

Of overall patients, 2 non-remission and 1 lateremission patients with cITP revealed antinuclear antibody (ANA) positivity (1/400). Median age at diagnosis of these patients was 6.5 years and median follow-up duration was 5 years, during which neither clinical nor pathological laboratory data were detected.

One male patient with non-remission cITP developed intracranial hemorrhage at the eighth month of diagnosis with a $\mathrm{PC}$ of $7 \times 109 / \mathrm{L}$; he did not respond to medical treatment and was splenectomized. None of the patients in the study group died.

\section{Discussion}

Immune thrombocytopenic purpura (ITP) is a common hemorrhagic disease with a heterogeneous background during childhood. It is likely that all pediatricians will encounter children with ITP at some time in their practice. There are still many questions to be answered regarding the natural progress of the clinical forms and the prediction of chronic or recurrent outcome, response to treatment and ultimate outcome [1-10].

Our results concerning the acute and chronic patients were comparable with other series in terms of the incidence of clinical courses, mean/ median age at diagnosis, male/female ratio, initial PCs, and initial response rates to therapy [12-15]. At present, it is difficult to foresee at the time of diagnosis the patients who will develop a chronic course; although age older than 10 years, adoles- 
Table 5. General characteristics and outcome of 25 patients with rTP

\begin{tabular}{|c|c|c|c|c|c|c|c|c|}
\hline No/sex & $\begin{array}{l}\text { Age at Dx } \\
\text { Months }\end{array}$ & $\begin{array}{l}\mathrm{PC} \text { at } \mathrm{Dx} \\
\left(\mathrm{x} 10^{9} / \mathrm{L}\right)\end{array}$ & $\begin{array}{l}\text { Days to achieve } \\
\text { initial } C^{* *}\end{array}$ & $\begin{array}{l}\text { Time of } 1^{\text {st }} \\
\text { recurrence } \\
\text { after } D x^{*}\end{array}$ & $\begin{array}{l}\text { Time of } 2^{\text {nd }} \\
\text { recurrence } \\
\text { after } D^{*} *\end{array}$ & $\begin{array}{l}\text { Time of } 3^{\text {rd }} \\
\text { recurrence } \\
\text { after } D^{*} *\end{array}$ & $\begin{array}{c}\text { Months elapsed } \\
\text { after last remission }\end{array}$ & $\begin{array}{c}\text { Total } \\
\text { follow-up* }\end{array}$ \\
\hline $1 / \mathrm{F}$ & 124 & 13,000 & 30 & 38 & & & 41 & 79 \\
\hline $2 / \mathrm{M}$ & 86 & 2000 & 30 & 16 & & & 23 & 39 \\
\hline $3 / \mathrm{F}$ & 95 & 19,000 & 15 & 8 & 12 & & 6 & 18 \\
\hline $4 / \mathrm{F}$ & 66 & 6000 & 20 & 71 & & & 6 & 77 \\
\hline $5 / \mathrm{M}$ & 45 & 20,000 & 5 & 12 & 22 & & 68 & 90 \\
\hline $6 / F$ & 98 & 7,000 & 10 & 9 & 20 & 70 & 6 & 76 \\
\hline $7 / \mathrm{F}$ & 41 & 13,000 & 30 & 60 & & & 36 & 96 \\
\hline 8/M & 51 & 5,000 & 60 & 30 & 37 & & 99 & 136 \\
\hline $9 / \mathrm{F}$ & 62 & 5,000 & 15 & 109 & 117 & & 24 & 141 \\
\hline $10 / \mathrm{M}$ & 22 & 8,000 & 20 & 13 & 19 & 67 & 53 & 120 \\
\hline $11 / \mathrm{F}$ & 125 & 4,000 & 30 & 25 & & & 68 & 93 \\
\hline $12 / \mathrm{F}$ & 52 & 30,000 & 10 & 61 & & & 80 & 141 \\
\hline $13 / \mathrm{M}$ & 120 & 4,000 & 10 & 36 & & & 96 & 132 \\
\hline $14 / \mathrm{M}$ & 48 & 20,000 & 30 & 34 & & & 19 & 53 \\
\hline $15 / \mathrm{M}$ & 151 & 5,000 & 40 & 26 & 48 & & 12 & 60 \\
\hline $16 / F$ & 45 & 6,000 & 90 & 9 & 34 & & 19 & 53 \\
\hline $17 \mathrm{~F}$ & 53 & 7,000 & 30 & 33 & & & 51 & 84 \\
\hline $18 / F$ & 56 & 4,000 & 45 & 12 & 24 & & 53 & 77 \\
\hline 19/M & 34 & 10,000 & 15 & 12 & 34 & 48 & 11 & 59 \\
\hline $20 / \mathrm{F}$ & 138 & 4,000 & 20 & 14 & & & 30 & 44 \\
\hline $21 / \mathrm{F}$ & 93 & 3,000 & 7 & 31 & & & 24 & 55 \\
\hline $22 / \mathrm{M}$ & 81 & 3,000 & 30 & 16 & & & 39 & 55 \\
\hline $23 / \mathrm{M}$ & 146 & 19,000 & 10 & 15 & & & 20 & 35 \\
\hline $24 / \mathrm{F}$ & 93 & 1,000 & 30 & 34 & & & 6 & 40 \\
\hline $25 / \mathrm{M}$ & 75 & 4,000 & 10 & 12 & & & 10 & 22 \\
\hline
\end{tabular}

*months

Dx: Diagnosis; ${ }^{* *} \mathrm{CR}$ : Complete response

cence in females, and an initial PC $>20 \times 10^{9} / \mathrm{L}$ have been associated with a chronic course [12-16]. In our study, initial PC $>20 \times 109 / \mathrm{L}$ and initial diagnosis age $>10$ years were found to increase the probability of chronic outcome by at least two-fold $(\mathrm{OR}=2)$. Glanz et al. [16] reported an approximate five-fold risk for progressing to chronic disease in children whose illness was diagnosed at $\geq 10$ years of age and who had PC $\geq 20 \times 109 /$ L. Kühne et al. [12] reported a high incidence of cITP (47.3\%) in older children and adolescents.

The majority of the children with cITP have mild bleeding episodes not requiring treatment despite persistent thrombocytopenia. In addition, rates of spontaneous recovery of $30-60 \%$ have been report- ed many years after initial diagnosis [6-8]. In our cohort, 102 patients with cITP were evaluated in non-remission and late-remission subgroups. Twenty-three patients (22.5\%) achieved complete remission in a median 18 months (8 months-66 months). In 16 of the 23 patients, PC normalized at 8-24 months. Currently, all of the patients in the lateremission group achieved complete remission, whereas $27.8 \%$ and $72.2 \%$ of the patients in the nonremission cITP subgroup revealed partial remission and no remission, respectively. Ruggiero et al. [6] reported 5 (41.6\%) out of 12 cITP patients approaching complete remission within 15-90 months. Donato et al. [8] reported a 32.9\% rate of spontaneous remission in 325 nonsplenectomized children 
with cITP between 6 months to 11 years; 44.9\% approached remission 6-12 months from diagnosis. In Jayabose et al.'s [7] series of 62 cITP patients, a $56 \%$ spontaneous remission rate was reported. All of these authors recommended delay or omission of surgical treatment and reservation of splenectomy for patients with severe symptoms and non-responders. Imbach et al. [14] and Donato et al. [8] also reported that the cut-off value to define cITP should be changed from 6 months to 12 months. Our observation, too, showed that the cut-off point of cITP should be changed to 12 months since immune thrombocytopenia could persist beyond 6 months and could recover spontaneously in months to years.

Recurrent ITP (rITP) is a rare clinical course of ITP. It was first described by Walker and Walker [11] in 1961, who defined it as recurrence of ITP after a prolonged remission. Later, Imbach [9] defined it as the recurrence of ITP after at least 3 months of remission (with normal PCs) sustained without any treatment, including splenectomy. Vranou et al. [19] defined rITP as isolated episodes of thrombocytopenic purpura following complete remission, nonrelated to therapeutic intervention, regardless of the time interval elapsed between the episodes, and reported that the time interval between two episodes less than 1-3 months was identified in $31.1 \%$ of the recurrences. Therefore, there is no consensus in the literature about the definition of rITP as to the interval between the episodes.

Since 1961, only series with small numbers of patients have been published on rITP [10,17-20]. Jayabose et al. [10] reported 14 (4.1\%) children with rITP among 340 pediatric patients. Median time to recurrence of these patients was 33 months (4-120 months). Twelve (86\%) patients had favorable outcome, with $71 \%$ achieving complete plus partial remission and $14.2 \%$ achieving complete remission after splenectomy. Vranou et al. [19] gave the incidence of rITP as $6 \%$ in their childhood ITP series. The majority of their rITP patients had only one recurrence (1-4 recurrences). The time interval between the two recurrences was longer than 3 months (up to 96 months) in two-thirds of the episodes. They observed that the initial episode and the first recurrence generally shared the features of aITP.

The incidence of rITP in our series was 7.1\% (25 of 350 patients), which is the highest of those reported by Khalifa et al. [18], Jayabose et al. [10] and Vranou et al. [19]. Within the follow-up period of 18-141 months, these patients experienced 1 to 4 recurrences. Sixty percent $(n=15)$ had only one,
$28 \%(n=7)$ had two, $8 \%(n=2)$ had three, and $4 \%$ $(n=1)$ had four recurrences. Median time elapsed to first recurrence after diagnosis was 20 months (8-109 months). The time interval before any recurrence was longer than four months (up to 50 months). It was also noted that these patients had low PC at initial diagnosis and at $1^{\text {st }}, 2^{\text {nd }}$ and $3^{\text {rd }}$ recurrences and had achieved complete remission at 5-11 days during the recurrence. In addition, rITP and aITP were found comparable in terms of PC at initial diagnosis and response rate to initial treatment, whereas rITP was found comparable to cITP regarding age at diagnosis. PCs at initial diagnosis and during the thrombocytopenic episodes in rITP patients were as low as seen in patients with aITP. We found that the bleeding manifestations in our rITP patients were more prominent in the initial presentation and in the first recurrence, in accordance with the study by Vranou et al. [19], and the bleeding manifestations were less than expected for the low PC in the $2^{\text {nd }}, 3^{\text {rd }}$ and $4^{\text {th }}$ recurrences.

There are contradictory reports on the classification of the patients with recurrences. rITP is believed by some to be an exacerbation during the course of a compensated cITP, probably triggered by viral infection [21,22]. In some reviews, it is mentioned as a separate form [10,18,19]. However, Roganovic et al. [20] reported that it could be characterized as "recurrent acute ITP" or what has been called by Dameshek et al. [17] "intermittent acute ITP". Dameshek et al. [17] showed that recurrent acute ITP was distinct from cITP since platelet survival between episodes was found normal. Our experience with rITP showed us that the majority of these patients generally shared the clinical and hematological features of aITP (low initial PC, high response rate to initial treatment, mild and self-limited course and excellent prognosis). None of these patients presented with major bleeding at any recurrence and none of the patients needed splenectomy. Even though most of these patients presented with low PCs at recurrences, responses to treatment were excellent. Preceding viral infection was noted in 16 patients at initial diagnosis. No previous history of vaccination or medication of any kind was detected at any recurrence. Unlike our favorable results in patients with rITP, Vranou et al. [19] and Jayabose et al. [10] reported 2 cases with rITP who developed intracranial hemorrhage, 1 being fatal. Also, 2 of 14 patients of Jayabose et al. [10] achieved complete remission after splenectomy. The discrepancy between the results of the study groups shows that 
definition, pathogenesis and outcome of rITP requires more data to be reported.

Splenectomy remains an effective therapeutic option for patients with cITP with severe symptoms and/or nonresponders to pharmacological treatment [23]. The rate of splenectomy performed for children with cITP ranges between $9 \%$ and $39 \%$ in the literature [23-27]. However, there are no currently available reliable factors predictive of whom and when to splenectomize and/or foresee the response rate to splenectomy. In our population of 102 cITP patients, 29.4\% $(\mathrm{n}=30)$ underwent splenectomy with a CR rate of $73.3 \%$ and a PR rate of $6.7 \%$. Median ages at initial diagnosis and at splenectomy were 8.5 years and 10.7 years, respectively. Fourteen patients underwent splenectomy between 8-16 months, 6 patients between 2-3 years and 8 patients more than 3 years after the initial diagnosis.

None of the children with ITP had serious bleeding manifestations within the total follow-up period except a three-year-old male patient who experienced an intracranial hemorrhage at the seventh month of diagnosis with a $\mathrm{PC}=7 \times 10^{9} / \mathrm{L}$, who had shown no response to pharmacological therapy; he was splenectomized. He is now six years old and is being followed in our hematology division without neurological sequelae and with PC at 30-50x109/L.

In conclusion, ITP in childhood is a hemorrhagic disease with diverse natural history. Its heterogeneous background and lack of long-term clinical data cause controversies in classifying and managing patients with ITP. Our experience shows that a late-remission course in patients with cITP should be considered and the cut-off value to define cITP should be changed to 12 months. Children with PC $>20 \times 10^{9} / \mathrm{L}$ at initial diagnosis and age at diagnosis $>10$ years have a two-fold risk for progression to chronic disease. rITP, a rare clinical course that seems to be mild and self-limiting and generally shares the clinical and hematological features of aITP, should also be considered. Splenectomy should be delayed and reserved for children with severe symptoms and/or non-responders. Prospective international long-term studies are needed to enlighten the natural history of the clinical courses and the final outcome in children with ITP.

\section{Acknowledgement}

The authors thank Prof. Hale Ören (Dokuz Eylül University, School of Medicine, İzmir, Turkey) for her contribution in revising the manuscript.

\section{Conflict of interest}

No author of this paper has a conflict of interest, including specific financial interests, relationships, and/or affiliations relevant to the subject matter or materials included in this manuscript.

\section{References}

1. Cines DB, Blanchette VS. Immune thrombocytopenic purpura. N Engl J Med 2002;346:995-1008.

2. Nugent DJ. Childhood immunothrombocytopenic purpura. Blood Rev 2002;16:27-9.

3. Kühne T. Immune thrombocytopenic purpura in childhood: controversies and solutions. Pediatr Blood Cancer 2006;47(5 Suppl):650-2.

4. Belletrutti M, Ali K, Barnard D, Blanchette V, Chan A, David M, Luke B, Price V, Ritchie B, Wu J; Canadian Pediatric Chronic ITP Working Group; Canadian Pediatric Thrombosis and Hemostasis Network. Chronic immune thrombocytopenic purpura in children: a survey of the Canadian experience. J Pediatr Hematol Oncol 2007;29:95-100.

5. Ozer EA, Yaprak I, Atabay B, Türker M, Akşit S, Sarığlu B. Oral cyclic megadose methylprednisolone therapy for chronic immune thrombocytopenic purpura in childhood. Eur J Hematol 2000;64:411-5.

6. Ruggiero A, Annunziata ML, Lazzareschi I, Ridola V, Attinà G, RiccardiR. Chronic immune thrombocytopenic purpura in children: case reports of spontaneous recovery without splenectomy. Pediatr Hematol Oncol 2006;23:471-5.

7. Jayabose S, Levendoglu-Tugal O, Ozkaynkak MF, Visintainer P, Sandoval C.. Long-term outcome of chronic immune thrombocytopenic purpura in children. J Pediatr Hematol Oncol 2004;26:724-6.

8. Donato H, Picón A, Martinez M, Rapetti MC, Rosso A, Gomez S, Rossi N, Bacciedoni V, Schvartzman G, Riccheri C, Costa A, Di Santo J. Demographic data, natural history, and prognostic factors of immune thrombocytopenic purpura in children: a multicentered study from Argentina. Pediatr Blood Cancer 2009;52:491-6.

9. Imbach P, Lilleyman JS, Hann IM and Blanchetter, V. S. (eds) (1999) Immune thrombocytopenic purpura. Pediatric Hematology, ed 2 Churchill Livingstone, London: Churchill Livingstone, 1999: 437-53.

10. Jayabose S, Levendoglu-Tugal O, Ozkaynak MF, Sandoval C. Recurrent immune thrombocytopenic purpura in children. Pediatr Hematol Oncol 2006;23:677-82.

11. Walker JH, Walker W. Immune thrombocytopenic purpura in childhood. Arch Dis Child 1961;36:649-57.

12. Kuhne T, Buchanan GR, Zimmerman S. Michaels LA, Kohan R, Berchtold W, Imbach P. A prospective comparative study of 2540 infants and children with newly diagnosed immune thrombocytopenic purpura (ITP) from the intercontinental childhood ITP study group. J Pediatr 2003;143:605-8. 
13. Watts RG. Immune thrombocytopenic purpura: a 10-year natural history study at the childrens hospital of Alabama. Clin Pediatr 2004;43:691-702.

14. Imbach P, Kühne T, Müller D, Berchtold W, Zimmeman S, Elalfy M, Buchanan GR. Childhood ITP: 12 months follow-up data from the Prospective Registry I of the Intercontinental Childhood ITP Study Group (ICIS). Pediatr Blood Cancer 2006;46:351-6.

15. Paling A, Stefan DC. Immune thrombocytopenic purpura in childhood: a 10-year audit. Hematology 2008;13:175-80.

16. Glanz C, France E, Xu S, Hayes T, Hambidge S. A population-based multisite, cohort study of the predictors of chronic idiopathic thrombocytopenic purpura in children. Pediatrics 2008;121:e506-12.

17. Dameshek W, Ebbe S, Greenberg L, Baldini M. Recurrent acute idiopathic thrombocytopenic purpura. N Engl J Med 1963;269:649-53.

18. Khalifa AS, Tolba KA, el-Alfy MS, Gadallah M, Ibrahim FH. Idiopathic thrombocytopenic purpura in Egyptian children. Acta Haematol 1993;90:125-9.

19. Vranou M, Platokouki H, Pergantou H, Aronis S. Recurrent immune thrombocytopenic purpura in childhood. Pediatr Blood Cancer 2008;51:261-4.

20. Roganovic J, Letica-Crepulja M, Dordevic L. Recurrent immune thrombocytopenic purpura in children. Pediatr Hematol Oncol 2008;25:243-4.
21. Wilson DB. Acquired platelet disorders. In: Nathan DG, Orkin SH, Ginsburg D, Look AT, editors. Nathan and Oski's Hematology of Infancy and Childhood. 6th ed. Philadelphia: WB Saunders, 2003: 1597-630.

22. Conradi A, Diaz de Heredia C, Tussel Puigbert J, Tobena Boada L, Ortega Aramburu JJ. Chronic and recurrent immune thrombocytopenic purpura. Ann Pediatr (Barc) 2003;59:6-12.

23. Donato H, Picón A, Rapetti MC, Rosso A, Schvartzman G, Drozdowski C, Di Santo JJ. Splenectomy and spontaneous remission in children with chronic immune thrombocytopenic purpura. Pediatr Blood Cancer 2006;47:737-9.

24. Mantadakis E, Buchanan GR. Elective splenectomy in children with immune thrombocytopenic purpura. J Pediatr Hematol Oncol 2000;22:148-53.

25. El-Alfy MS, El-Tawil MM, Shahein N. 5- to 16-year follow-up following splenectomy in chronic immune thrombocytopenic purpura in children. Acta Haematol 2003;110:20-4.

26. Wang T, Xu M, Ji L, Yang R. Splenectomy for chronic immune thrombocytopenic purpura in children: a single center study in China. Acta Haematol 2006;115:39-45.

27. Yetgin S, Olcay L, Ozsoylu S, Hiçsönmez G, Gurgey A, Tuncer AM. Retrospective analysis of 78 children with chronic ITP: follow-up from 1976-1996. Pediatr Hematol Oncol 1997; 14:399-412. 